

\title{
WHO WAS NEHEMIAH BEN HACALIAH?*
}

\author{
LISBETH S. FRIED \\ UNIVERSITY OF MICHIGAN
}

The book of Nehemiah begins with the phrase: "The words of Nehemiah son of Hacaliah" (Neh 1:1), but who was this man? Who is, or who was Nehemiah ben Hacaliah? The book of Nehemiah uses this phrase as a superscription, a superscription, which if taken literally, implies that all the subsequent chapters in the book which were written in the first-person singular are the very own words of Nehemiah ben Hacaliah. But who was this man?

This superscription, "the words of Nehemiah," has prompted exegetes at least since Rashi to conclude that the entire book of EzraNehemiah from this point on was written by someone named Nehemiah, who was both cupbearer to Artaxerxes (Neh 1:11) and a fifth-century governor of the Persian province of Judah (Neh 5:14). Clines calls this first person account in Nehemiah "our most valuable and clearly authentic source for the history of the postexilic age."1 Grabbe states that "the existence of such a writing [as this first-person account] by one of the leading participants in the events of the time is a real bonus for the historian." 2 He assigns Neh 1:1-7: 5, portions of 12:27-43, and 13:4-31 to an authentic Nehemiah, writing in the fifth century. Williamson is more circumspect but agrees that "substantial parts of the [first-person account] go back to a firstperson account by Nehemiah himself." 3

Nevertheless, the phrase, "The words of Nehemiah son of Hacaliah" (Neh 1:1), which begins the book, is a superscription, and a superscription is simply "a third-person statement prefixed to a written work that precedes and stands outside of it." 4 Superscriptions that introduce prophetic books (e.g. Amos 1:1; Jer. 1:1, etc.)

\footnotetext{
* I would like to thank the anonymous reviewers who were instrumental in making this a much better and much more focused paper than it had originally been.

${ }^{1}$ D.J. Clines, Eqra, Nehemiah, Esther (The New Century Bible Commentary; Grand Rapids: Eerdmans, 1984), 136.

${ }^{2}$ L.L. Grabbe, Eqra-Nehemiah (OTR; London: Routledge, 1998), 155.

3 H.G.M. Williamson, Ezra, Nehemiah (WBC 16; Waco, TX: Word, 1985), xxiv.

${ }^{4}$ L.W. Batten, The Books of Ezra and Nehemiah: A Critical and Exegetical
} 
are universally considered to be added by scribes who took down and compiled the prophet's spoken words. Superscriptions are never considered to have been spoken or written by the prophet himself. The books of Jeremiah, Amos, and Ecclesiastes also begin this way, that is, Jeremiah begins with "The words of Jeremiah son of Hilkiah" (Jer 1:1). Amos begins with "The words of Amos" (Amos 1:1), and Ecclesiastes begins with "The words of the preacher" (Eccl 1:1). In all these cases, the phrase "the words of" should more accurately be translated as "the legacy of Jeremiah," or of Amos, etc., not "the words of." 5 Thus, we should rather translate as "the legacy of Nehemiah" rather than "the words of," since not only the protagonists' words, but also their deeds, are presented in their books. The phrase in $1 \mathrm{Kgs}$ 11:41, literally "the rest of the words of Solomon," for example, is usually translated as "the rest of the acts of Solomon." The reference to "the words of the preacher" in Eccl 1:1 is often viewed as referring to the words of King Solomon who was "son of David, king in Jerusalem" as the text says (1:1), but research has pointed to the Persian or Hellenistic periods as the time of writing, ruling Solomon out. ${ }^{7}$ Thus, the superscription here in the book of Nehemiah as well, being written by a third party, may have been written much later and may not contain any historical information about the author or authors of the text which follows it.

Nevertheless, it is only because of the superscription that we interpret Nehemiah's as the voice behind the first-person account. But where did this superscription come from? Who added it, and why? It must be stressed that nowhere in the first-person account in the book of Nehemiah is the name of the speaker given. No one calls the speaker by that name, or indeed by any name. So how did the editor who added the superscription decide it was Nehemiah's voice speaking throughout, and how did he know his name and patronym? Williamson assumes that it must have been included in the material inherited by the editor even if he did not report it in the text that we have. ${ }^{8}$ There is no evidence for this theory, however.

This article examines the first-person account(s) in the book of Nehemiah in an attempt to determine how this name may have become attached to the protagonist(s). The goal is first of all to determine if there is more than one first-person account and if so,

Commentary (ICC; Edinburgh: T\&T Clark, 1913), 182; G.M. Tucker, "Prophetic Superscriptions and the Growth of the Canon," in Canon and Authority: Essays in Old Testament Religion and Theology, ed. G.W. Coats and B.O. Long (Philadelphia: Fortress, 1977), 56-70, esp. pp. 57-8.

5 As for example, J.R. Lundbom, Jeremiah 1-20, A New Translation with Introduction and Commentary (The Anchor Bible 21A; New York: Doubleday, 1999), 222.

${ }^{6}$ C.-L. Seow, Ecclesiastes, A New Translation with Introduction and Commentary (The Anchor Bible 18C; New York: Doubleday, 1997), 36-8.

7 J. Murphy-O'Connor, The Holy Land: An Archaeological Guide from Earliest Times to 1700 (New York: Oxford University Press, 1992), xxii-xxiii.

${ }^{8}$ Williamson, Ezra, Nehemiah, 166. 
to isolate them. Secondly, an attempt is made to determine if any of the first person accounts belong to an historical figure or if they are all literary. Third, if it can be determined that Nehemiah ben Hacaliah was an historical figure, then the third goal is to discover who he was and when he lived.

\section{Previous Theories Regarding THE NEHEMIAH MEMOIR}

Williamson has discussed five scholarly views regarding the first person account(s) in the book of Nehemiah, ${ }^{9}$ to which I add Wright's view, composed after Williamson wrote, as number six and Williamson's own view as number seven:

A. The first view is that of Mowinckel, who argued that the form of the first person account in Nehemiah was based on the royal inscriptions of ancient Near Eastern kings. ${ }^{10}$

B. Von Rad supplemented Mowinckel's thesis by also comparing the Nehemiah Memoir to tomb and temple memorial inscriptions from Egypt. ${ }^{11}$ These include inscriptions not only of kings but of high civil servants and royal officials as well.

C. A third view proposes that the form of the Nehemiah memoir goes back to Aramaic votive inscriptions. ${ }^{12}$

D. A fourth view is simply that Nehemiah wrote to justify himself to the Persian king in the face of accusations of rebellion against the king. ${ }^{13}$ This view is assumed by Becking, but he also asserts that the view can neither be verified or refuted. ${ }^{14}$

E. In a fifth approach, similar to the above, Kellermann compares the Nehemiah memoir to the type of Psalm known as the "Prayer of the Accused." 15

F. A sixth approach is that proposed by Jacob Wright which he helpfully outlines on p. $340 .{ }^{16}$ Wright understands the book of Nehemiah to have been composed in seven stages

\footnotetext{
${ }^{9}$ Williamson, Ezra, Nehemiah, xxiv-xxviii.

${ }^{10}$ S. Mowinckel, Die Nehemia-Denkschrift, Studien zu dem Buche Ezra-Nehemia II (Oslo: Universitetsforlaget, 1964), 50-92.

11 G. von Rad, "Die Nehemia-Denkschrift," ZAW 76 (1964): 176-87.

12 W. Schottroff, "Gedenken" im alten Orient und im Alten Testament (WMANT 15, 2nd ed.; Neukirchen-Vluyn: Neukirchener Verlag, 1967), 218-22, 292-3.

13 Williamson, Eqra, Nehemiah, xxv.

14 B. Becking, Eqra-Nehemiah (HCOT 10; Leuven: Peeters, 2018), 7.

15 U. Kellermann, Nehemia: Quellen, Überlieferung, und Geschichte (Berlin: Töpelmann, 1967), 76-84.

${ }_{16}$ J.L. Wright, Rebuilding Identity: The Nehemiah-Memoir and Its Earliest Readers (BZAW 348; Berlin: de Gruyter, 2004).
} 
over a very long period of time. The first layer consists of the earliest report of Nehemiah's building account including his appointment to that role. The second layer includes the register of builders in Neh 2 and 3. The third layer includes the reactions-positive and negative- to the wall. The fourth and fifth strata include references to Nehemiah as governor. Thus, his approach does not recognize that the report of the governor may be authentic and may go back to an actual fifth-century governor of Yehud. The sixth layer includes the references to rebuilding the city, primarily in chapters 11 and 12 . The final additions include chapters 1 , parts of 7-10, and 12 and 13.

G. A different approach is the one taken here and which was adumbrated by Williamson in his 1985 commentary. ${ }^{17}$ Williamson points to the long unexplained chronological gap between the report of the wall-builder, and the report of the governor twelve years later, a gap which Wright also builds on. Williamson points as well to the numerous "remember" statements in which the speaker asks God to remember him for all the good he has done for Jerusalem and for the people Israel, yet which never refer to the wall! He also points out that Neh 10 , which is basically a contract in which the signers agree to provide for the temple in Jerusalem, cannot have been part of the Nehemiah memoir. He concludes that Nehemiah was appointed for a short amount of time to rebuild the wall and that the bulk of the book contains his report to the king on that work, a report originally written in Aramaic. Williamson suggests that Nehemiah then reworked the report much later after he was subsequently appointed governor. What Williamson has strikingly pointed out, however, a fact which Wright recognizes and builds on, is the basic incompatibility between the two I-reports, that of the wall-builder and that of the governor. Williamson has not admitted this, but what he and Wright have shown is that the two I-reports could not have been written by the same person. Even someone writing twelve years later would not ignore or forget that he had built the wall around Jerusalem, and would not have ceased bragging about it. This wall was even lauded by Ben Sira writing in the second century BCE.

The present proposal builds on both Wright and Williamson's work, but goes beyond them. Rather than a text being added to by multiple people over generations, as Wright suggests, or a text that one person has written at two different times, as Williamson proposes, I suggest that there were in fact two separate and genuine I-reports, two reports written by two different men. These were later combined by

\footnotetext{
17 Williamson, Eqra, Nehemiah, xxvi-xxviii.
} 
the biblical writer. To this he added a third document, a genuine contract in which the undersigned agree to maintain the new temple in Jerusalem and support its personnel. The first I-report was written by a wine steward who was commanded by the king to build a wall around Jerusalem and then to quickly return. The second I-report was written by the governor of Judah, also appointed by that same king in that same twentieth year. It was this second man who wrote the "Remember me for good" sayings, and because he did not build the wall, he does not ask to be remembered for it. A third person, and perhaps the only one actually named Nehemiah, is the one who was the first to sign the temple contract now in Neh 10. Thus rather than one person writing at two separate time periods (e.g., Williamson) and rather than a single book being added to over centuries in successive stages (e.g., Wright), I propose that the book of Nehemiah contains two separate and perhaps genuine I-reports written by two separate men (one, the cup-bearer cum wall-builder, and one, the fifth-century governor of Yehud) which were woven together by the biblical writer. To this the biblical writer added the temple document now in Neh 10. He then added his own third person accounts. Each of these protagonists is discussed in turn:

\section{The Cupbearer to THE KING}

At the beginning of chapter 2 of the book of Nehemiah, we read the following first-person statement.

And it was in the month of Nisan, in the 20th year of Artaxerxes, the King, [when I was serving] wine before him, that I took up the wine and gave it to the king. (Neh 2:1)

The Hebrew actually reads only "wine before him." The single word "I was serving" seems to have dropped out of the text. In any case, the first protagonist, the speaker of the first I-report, is from someone who was a cup-bearer, a wine steward, to Artaxerxes the king in the king's twentieth year.

We then read the following conversation between the king and this wine-steward:

${ }^{4}$ And the king said to me, "What is this that you request?" ... 5Then I said to the king, "If it seems good to the king, and if your servant has found favor with the king, may you send me to Judah, to the city of the graves of my ancestors, that I may rebuild it." "Then the king said to me...: "How long until your trip, and when will you return?" So it pleased the king, and he sent me, and I gave him a time. (Neh 2:4-6)

Thus the king has appointed the speaker, his wine-steward, to rebuild Jerusalem's walls. It is clear from the king's question asking when he would return that the king was not appointing his cupbearer to any other task, but only to repair the city's walls. He was not being 
appointed to be governor of Judah, for example. ${ }^{18}$ For that post there is no fixed end date, it is ended at the will of the sovereign.

\section{GOVERNOR OF JUDAH}

Whether or not it was the wine steward himself, someone speaking in the first person was indeed appointed to be governor of Judah in the king's twentieth year. We read as much in the following text (Neh 5:14):

From the day that he commanded me to be their governor in the land of Judah, from the twentieth year until the thirty-second year of King Artaxerxes, twelve years, neither I nor my fellows had consumed the bread of the governor.

The phrase "bread of the governor" likely translates the Akkadian kurummat bèl pihati, literally "the (food or bread) rations of the governor." This type of official nomenclature continued into the Achaemenid period, reinforcing the hypothesis that we have here included in the book of Nehemiah the report of a genuine Persian governor of Yehud. Further, his report that he served 150 men at his table every day (Neh 5:17) seems not to have been fabricated. ${ }^{19}$

We have again a nameless speaker, but one claiming to have been appointed governor of Judah in the twentieth year of King Artaxerxes, the same year that the wine-steward was appointed to rebuild Jerusalem's city walls. These cannot be the same person, however. If the wine-steward had also been appointed to the role of governor, he would have mentioned somewhere in his memoir of his new appointment and of his resulting elevation in status. ${ }^{20}$ That he does not mention it implies that they may not be the same person, and that it is simply a coincidence that they were both appointed that same year.

In point of fact, we know the name of the man who was governor of Judah in the twentieth year of Artaxerxes I, that is, in 445 BCE. It is Yeho'ezer. We know that Yeho'ezer was governor of Yehud in the mid-fifth century because we have his seals!21

18 U. Kellermann, Nehemia: Quellen, Überlieferung, und Geschichte, 12, with note 31; Williamson, Ezra, Nehemiah, 180.

${ }^{19}$ L.S. Fried, "150 Men at Nehemiah's Table? The Role of the Governor's Meals in the Achaemenid Provincial Economy," JBL 137 (2018): 821-31.

20 Pace to all those who have suggested that Nehemiah was either appointed governor then or was promoted shortly after his arrival in Judah: E.g., Kellermann, Nehemia: Quellen, Überlieferung, und Geschichte, 12; A.H.J. Gunneweg, Nehemia, (KAT XIX 2; Gütersloh: Gütersloher Verlagshaus, 1987), 54; J. Blenkinsopp, Ezra-Nehemiah a Commentary (OTL 14; Philadelphia: Westminster, 1988), 214.

21 O. Lipschits and D. S. Vanderhooft, The Yehud Stamp Impressions: A Corpus of Inscribed Impressions from the Persian and Hellenistic Periods in Judah (Winona Lake, IN: Eisenbrauns, 2011), 192-201. 
Seven stamped seal impressions, definitely dated to mid-fifth century BCE, have been found. Five were from Ramat Rahel, the probable location of the governor's mansion. ${ }^{22}$ These bear the following Aramaic inscription:

\section{יהוד יהועזר פחוא}

Yehud, Yeho'ezer, the governor

Yeho'ezer was thus the name of the governor of Judah during the reign of Artaxerxes I, the mid-fifth century. He was followed in the late fifth century by a governor named Bagavahya. In 407 the Judeans of Elephantine sent a letter addressed to Bagavahya, governor of Yehud (TAD A. 4.7). The letter states that they had written to him for his help as governor three years before (1l. 17-18), so he was governor in 410 as well. He was probably governor throughout the reign of Darius II (423-405) and likely immediately followed Yeho'ezer as governor of Yehud.

Thus, rather than a governor named Nehemiah, we may have before us, incorporated into the book of Nehemiah, an authentic gubernatorial report of Yeho'ezer, the actual governor of Yehud during the mid-fifth century, the period of Artaxerxes I. It may be his report that the biblical writer has incorporated into his book now called "Nehemiah." Yeho"ezer's name means "Yhwh helped," indicating that this Persian governor was of Judean ancestry and worshipped Yhwh.

Thus, either the name of the wall-builder was Yeho'ezer and he was subsequently named governor, or the author of our book has conflated at least two separate I-reports, one of a cupbearer turned wall-builder, and a second one, one of Yeho 'ezer himself, who was governor of Judah in the mid-fifth century (Neh 5:14). Nevertheless, this does not tell us who Nehemiah ben Hacaliah is. Was he the wallbuilder or was he someone else?

\section{NEHEMIAH ATTIRŠĀTĀ BEN HACALIAH}

Neither the wine-steward cum wall-builder nor the governor of Judah in the mid-fifth century is ever called Nehemiah in the book of Nehemiah. Nevertheless, someone, in fact, is called Nehemiah in

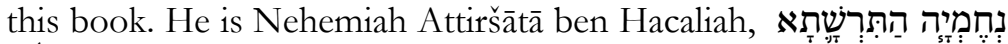

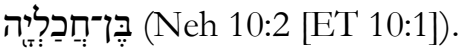

The word Attiršātā, usually spelled hattiršătā', is most often translated into English as "the governor" (cf. the NRSV). ${ }^{23}$ Unfortunately this is based on an outdated etymology. Tarsa means "to

${ }^{22}$ Ibid.

23 As well as most recently by L.S. Fried, Ezra: A Commentary (Sheffield Phoenix Critical Commentary Series 1; Sheffield: Sheffield Phoenix, 2015), 131; D.N. Fulton, "What Kind of Governor Was Nehemiah? The Titles

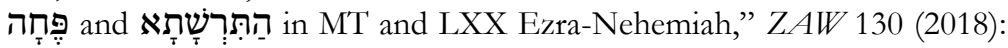


fear" in Old Persian, ${ }^{24}$ so it has been assumed that in hattiršata $\bar{a}$ ' we find $h a$, the Hebrew "the," and "tarša," the Persian word for "frightened," or "trembling in fear." Thus the term was translated in commentaries as "the one who is feared," that is, as "Excellency" or as "the governor." The difficulty with this is that "tarša" never refers to the one feared, but always to the one who is frightened. ${ }^{25}$ Moreover, there is no Iranian, Persian, Elamite, or Akkadian title remotely similar to hattiršătă', or even tiršătä. ${ }^{26}$

Rather than assuming that the initial bat is the Hebrew definite article "the", indicating some sort of title, the prefix hattir is more likely a corruption of "Att'r", and refers either to Atr, the Persian fire [god] or to the West-Semitic goddess Attr, ${ }^{27}$ associated with the planet Venus. ${ }^{28}$ The second element, $\check{s}(y)$ ata, is a common component of Iranian personal names and means "prosperous," "happy," or "blissful." 29 The word is now considered simply to be the personal name *Atr-š(iy)ata meaning "Prosperous or Happy through Atr/Attr," that is, "through, or by means of, the god/goddess Atr/Attr." ${ }^{30}$ Thus, the Nehemiah referred to in Neh 10 as the first signer of the temple contract seems to have had two personal names, a Persian name, Attršiata, for dealing with the Persians and a Hebrew one, Nehemiah, when interacting with his fellow Judeans.

This is expressed explicitly in Neh 8:9:

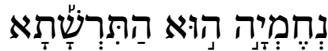

Nehemiah, he is Attiršātā

252-67; B. Becking, Ezra-Nehemiah, 283.

24 R.G. Kent, Old Persian: Grammar, Texts, Lexicon (New Haven: American Oriental Society, 1953), 186.

${ }^{25}$ P.O. Skjaervo, "Review of Persia and the Bible by Edwin M. Yamauchi," JAOS 114 (1994): 499-504, esp. 501.

${ }^{26} \mathrm{~J}$. Tavernier, "Review of Manfred Hutter, Iranische Personennamen in der Hebräischen Bibel," AfO 54 (in press).

${ }^{27}$ É. Benveniste, Titres et Noms Propres en Iranien Ancien (Paris: Klinksieck, 1966), 120; R. Zadok, "Some Issues in Ezra-Nehemiah," in New Perspectives on Ezra-Nehemiah: History and Historiography, Text, Literature and Interpretation, ed. I. Kalimi (Winona Lake, IN: Eisenbrauns, 2012), 151-81, esp. pp. 1601 , and see references there; C. Tuplin, "Serving the Satrap: Lower Rank Officials Viewed Through Greek and Aramaic Sources," in Die Verwaltung im Achämenidenreich/Administration in the Achaemenid Empire, ed. B. Jacobs, W.F.M. Henkelman, and M. Stolper, (Classica et Orientalia 17; Wiesbaden: Harrassowitz, 2013), 613-76, esp. 615, fn. 3; A. Lemaire, “Atarshamain,” in The Routledge Encyclopedia of Ancient Mediterranean Religions, ed. Eric Orlin et al. (New York: Routledge, 2015), 104-5.

${ }^{28}$ Lemaire, "Atarshamain."

${ }^{29}$ Kent, Old Persian, 210-1.

30 The pronunciation of the vowel is not known. 
The full name "Nehemiah Attiršātā ben Hacaliah" appears in Neh 10 (Neh10:2 [ET 10:1]) as the first signer of a document which commits the undersigned to the care of the temple. This document is often seen as forming the climax of the book Ezra-Nehemiah, for in this section the people are seen as finally committing themselves to the law. ${ }^{31}$ In Neh 8, Ezra reads the torah of Moses to all the people, who weep when they hear it. He admonishes them to be glad, for joy in Yhwh is strength. The people celebrate, eat, drink, and send gifts (Neh 8). The Levites then recount God's wonders toward them from the time he brought them out of Egypt to the present, and they confess that in spite of everything that God has done, they and their ancestors have been disobedient (Neh 9). Because Yhwh is a just god, he has handed them over to the peoples of the lands, thus making them slaves in their own country to the foreign kings that God has set over them (Neh 9). Now, according to Neh 10, it is because of all this (the law-reading and the long prayer of confession) that they, the undersigned, with Nehemiah Attiršàtā ben Hacaliah at their head, make a firm agreement (an 'Amānäh) to keep the Torah of Yhwh and never forsake his temple. As when they read the laws of Sukkot and then followed them in Neh 8, here too authority is transferred from human leaders to a written text. ${ }^{32}$ The people concretize their oath to the temple and their god by affixing their seals to a written document, a written contract, an 'Amānäh, which they swear to uphold.

A major historical question has been the date of this document. Many commentators date it to the governor's second term, just after the events of Neh 13, and interpret it as a response to those events. ${ }^{33}$ Japhet sees the 'Amänäh of Neh 10 as much later than either of the governor's terms, however, ${ }^{34}$ and as stemming from the period of Ezra, whom she dates to Artaxerxes II. ${ }^{35}$ It cannot have come from the time of Ezra however, since Ezra is not a signatory. Ezra certainly would have signed it had the document originally been a response to the events described in Neh 8 and 9, and had he actually been present. ${ }^{36}$ It is true that someone named Azariah did sign it

31 W. Rudolph, Esra und Nehemia Samt 3.Esra (Tübingen: Mohr Siebeck, 1949), 173; K. Baltzer, The Covenant Formulary in Old Testament, Jewish, and Early Christian Writings, trans. D. Green; (Philadelphia: Fortress, 1971), 438; M.W. Duggan, The Covenant Renewal in Eara-Nehemiah (Neb 7:72b-10:40): An Exegetical, Literary, and Theological Study (SBL Dissertation Series 164; Atlanta: Society of Biblical Literature), 2001, 5-7.

32 T.C. Eskenazi, In an Age of Prose: A Literary Approach to Ezra-Nehemiah (Atlanta: Scholars Press, 1988), 1, 2, 5.

${ }^{33}$ E.g., D J. Clines, "Nehemiah 10 as an Example of Early Jewish Biblical Exegesis," JSOT 21 (1981): 111-17; Williamson, Eqra, Nehemiah, 351; Gunneweg Nehemia, 131.

${ }^{34}$ S. Japhet, Ezra-Nehemiah: Introduction and Commentary (Mikra LeYisra'el; ed. S. Ahituv; Tel Aviv: Am Oved, 2019), 403-5 [Hebrew].

35 Ibid, 183

${ }^{36}$ Rudolph, Esra und Nehemia, 173. 
(10:3 [ET 10:2]), and that Ezra is a shortened form of this name. Nevertheless, our Ezra is never referred to in this way, but always and only simply as Ezra.

It is more likely that this document pre-existed its appearance in the book of Ezra-Nehemiah. Except for the brief reference to mixed marriages (v. 31 [ET 30]), there is no concern in all of EzraNehemiah, not even in the prayer of confession of Neh 9, for any of the provisions enumerated in this document. ${ }^{37}$ Nor can the obligations imposed on the community that are described here be a response to the events in Neh 13 as the language is not the same. ${ }^{38}$ Nor is the document a construction of the biblical writer. The second signer, Zedekiah, is not known, and had the document been a fabrication, a well-known name would certainly have been used. ${ }^{39}$

As almost all commentators agree, ${ }^{40}$ the author most likely took this document directly from the temple archive. The disagreement has only involved the date of the document-before or after Neh 13, i.e., before or after the governor's second term of office in Judah.

A third date is also possible. The first signer is Nehemiah Attiršātā ben Hacaliah, so realizing now that Attiršātā is a Persian personal name, and not a title, it may allow us to date the document. This is because we also read that there was a man named Attiršătā who was actually in charge of the temple priesthood, not during the reign of Artaxerxes however, but at the time of the first return under Zerubbabel and Jeshua in 520. We read:

${ }^{61} \mathrm{Also}$, of the descendants of the priests: the descendants of Habaiah, Hakkos, and Barzillai (who had married one of the daughters of Barzillai the Gileadite, and was called by their name). ${ }^{62}$ These looked for their entries in the genealogical records, but they were not found there, and so they were excluded from the priesthood as unclean; ${ }^{63}$ Attiršata said to them that they must not eat from the most holy food until a priest arises with urim and thummim. (Ezra 2:63 = Neh 7:64 [ET 7:65])

Rather than translating (Ezra 2:63 = Neh 7:64 [ET 65]) as "the governor said to them" (e.g., NRSV), we know now that Attršiyata is a personal name, so that it was actually someone named Attršiyata who admonished them. This man named Attršiyata had charge of the temple at the time of the return to Judah. It was he who had the authority to tell certain priests at that time that they may not partake of the most holy food until a priest came with Urim and Thummim (Ezra 2:63= Neh 7:64 [ET 7:65]). We also know that this same man was very wealthy, and that he gave huge sums to the temple building fund (Neh 7:69 [ET 7:70]).

${ }^{37}$ Rudolph, Ibid., 173; Wright, Rebuilding Identity, 212.

${ }^{38}$ Rudolph, Ibid.; Clines, Eqra, Nehemiah, Esther, 200; Gunneweg Nehemia, 131; pace Clines, "Nehemiah 10”; Williamson, Ezra, Nehemiah, 351.

${ }^{39}$ Rudolph, Esra und Nebemia, 174.

40 Pace Wright, Rebuilding Identity, 213. 
Unless there were a lot of people named Attršiyata in Persian period Judah, then the man Attršiyata who was in charge of temple personnel in the days of the return and who then made the huge donation to the temple, must be the same Attršiyata who was the first to sign a document committing temple priests and Levites to the temple's upkeep. Indeed, we know no other Attršiyata. The name does not appear in any of our contemporary documents from either Judah, Samaria, or Elephantine, or any of the Akkadian or Aramaic documents from the Achaemenid period in Iraq or Bactria. Thus, we may conclude that it was this same Nehemiah Attršătā who both signed the 'Amāna and who directed the priesthood during the days of the first return, at the time of Cyrus and Darius (Ezra 2:63 =Neh 7:65). Accordingly, we should date this document in Neh 10 to the days of the first return as well. Indeed, studies of the list of names of the signatories indicate that the list of names in Neh 10 is among the earliest of all the lists of names appearing in Ezra-Nehemiah. ${ }^{41}$ Thus, this document, now in Neh 10, seems to have been the temple's actual foundation document, written at the founding of the second temple in Jerusalem, and written to create an association of priests, Levites, and laity to care and provide for the new temple. ${ }^{42}$

\section{TEMPle Associations}

Solon's Law on Associations, probably written in Athens in 594 BCE, provides a contemporary understanding of associations of temple priesthoods:

If a demos ( $\delta \tilde{n} \mu \circ \varsigma)$ or members of a phratry or of a cultic society (ỏ $\gamma \tilde{\omega} v \varepsilon \varsigma$ ) or of a ship-command or messmates or members of a burial society or revelers or people going abroad for plunder or for commerce make an arrangement concerning these matters [i.e. matters appropriate to their association] among themselves, it is to be valid unless the written statutes of the people forbid it. ${ }^{43}$

According to this law-which legalizes them-an association is simply a group of people capable of issuing binding edicts on its members. Such a group may be permanent and lasting over many generations like the phratry or the demos, or it may be transient like the men who agree on a common commercial or military venture. The group may have been organized for a public purpose (like the

41 J.M. Myers, Eqra-Nehemiah (Anchor Bible Commentary 14; New York: Doubleday, 1965), 176; A. Jepsen, “Nehemia 10,” ZAW 66 (1954): 87-106.

${ }^{42}$ L.S. Fried, "A Greek Religious Association in Second Temple Judah? A Comment on Nehemiah 10," Transeu 30 (2005): 75-93.

43 Gaius's Digest 47.22.4, apud N.F. Jones, The Associations of Classical Athens : The Response to Democracy (New York-London: Oxford University Press, 1999), 34. 
phratry or the demos) or for a purely private purpose (like the revelers). Membership may be voluntary (as with the revelers) or involuntary (as with the demos). The crucial distinction is that the group of people be capable of regulating themselves by enforceable rules.

One type of association cited by Solon is the cult guild (ó $\gamma \tilde{\omega} v \varepsilon s)$. Temple cultic associations were well known throughout the Greco-Persian world. Weisberg has recognized a craftsmen's guild at the temple of Eanna in Uruk from the fourth year of Cyrus. ${ }^{44}$ De Cenival and others have documented associations of temple priests in Egypt as early as the 29th year of Amasis (541 BCE), ${ }^{45}$ and N.F. Jones has studied the cultic associations of classical Athens (594-321 BCE). ${ }^{46}$ The ubiquity of the institution makes it reasonable to propose that a cultic association also existed at the temple of Yhwh in Jerusalem at its founding and to suggest that its foundation document lies behind the text of Neh $10 . .^{47}$ Indeed, the structure and content of the Amanab in Neh 10 has been positively compared to that of a foundation document of a Ptolemaic Egyptian cultic association (6-nt, demotic sn.t or swn.t) and to that of the Babylonian craftsmen's guild. 48

Similarity of structure, content, and purpose suggest that Neh 10 may have been the actual foundation document for a cultic association of the Jerusalem temple, written at the time of the temple's dedication in 516 BCE. To begin with, the document is written in the first-person plural like other cult associations, although there are recognizable late third-person additions to it (i.e. vv. 29-30). ${ }^{49}$ The third-person passages in the text were likely added to cause the document to appear as the culmination of the so-called covenant renewal ceremony of Neh 8-10. It is clear, however, that the bulk of the measures agreed to are not the result of a legal enactment from above, but are the result of a mutual agreement that lays out the groundwork for running the temple. ${ }^{50}$

Rather than written for its present context, this document in Neh 10 was likely the foundation document for the temple of Jerusalem when it was first built and dedicated in the days of Cyrus and Darius I. It would have served to establish the original rules for the

${ }^{44}$ D. Weisberg, Guild Structure and Political Allegiance in Early Achaemenid Mesopotamia (New Haven: Yale University Press, 1967).

${ }^{45}$ F. de Cenival, Les Associations Religieuses en Égypte d'Après les Documents Démotiques (Cairo: Impr. de l'Institut français d'archéologie orientale, 1972); eadem, "Comptes d'une Association Religieuse Thébaine Datant des Années 29 à 33 du Roi Amasis," REg 37 (1986): 13-29; G. R. Hughes and H. Junker, The Sixth Day of the Lunar Month and the Demotic Word for "Cult Guild" (Wiesbaden: Harrassowitz, 1958); B. Muhs, "Membership in Private Associations in Ptolemaic Tebtunis," JESHO 44 (2001): 1-19.

46 Jones, The Associations of Classical Athens.

${ }^{47}$ Fried, "A Greek Religious Association in Second Temple Judah?"

48 Ibid.

${ }^{49}$ Ibid.

${ }^{50}$ Batten, The Books of Ezra and Nehemiah, 373. 
temple's cult guild or association in its role of providing for the temple, as well as the rules for its priests and Levites. If so, we may have at its base a copy of an authentic document, written and signed when the temple was first dedicated on the twenty-third of Adar II, in 516 BCE. ${ }^{51}$

\section{THE SUPERSCRIPTION-AgAIN}

If so, if the above is correct, we are back to the superscription, again. Why did the biblical editor assume that the I-voice in the book of Nehemiah belonged to Nehemiah Attiršàtā ben Hacaliah, if he in fact lived so long before the time of the wall's actual rebuilding?

It seems likely that this editor based his superscription on the fact that the first signer of the temple document, the contract now in Neh 10, is identified as Nehemiah son of Hacaliah (10:2 [ET 10:1]). Since a first-person speaker in the book of Nehemiah identifies himself as a governor of Judah (pehâ, 5:14; writer who added the superscription may simply have assumed that the first person to sign the contract would of course have been that governor and that the speaker throughout both I-reports was the same and was that same governor and that this was his name. It is a natural enough assumption, but it is wrong. We do not know the name of the wall-builder, and we may assume the name of the governor to be Yeho'ezer, the man who was indeed the governor of Yehud in the mid-fifth century. Nehemiah Attiršàtā ben Hacaliah may also have been a governor of Yehud, but if so, it would have been during the sixth century, at the time of the founding of Jerusalem's second temple.

It is true that Ben Sira (ca. 190 BCE) asserts that the name of Jerusalem's wall builder was Nehemiah (Ben Sira 49:13), even though, except for this superscription at Neh 1:1, it is nowhere stated in the text that we have. Although Ben Sira apparently did not yet know the story of Ezra, since Ezra is never mentioned in his praise of the fathers, the version of Nehemiah that he had must have already included the superscription at Neh 1:1, as well as the whole text of Neh 10, from which the superscription was derived, since he includes Nehemiah but not Ezra in his praise of famous men.

\section{CONCLUSIONS}

It may be concluded that there are two separate protagonists in the book of Nehemiah, each speaking in the first person. One is the wine-steward of King Artaxerxes I who was permitted by that king to go to Jerusalem for a few months to rebuild the wall around that city. We do not know his name. He is never addressed directly. The second protagonist is the governor of Judah who was also appointed

${ }^{51}$ Fried, "A Greek Religious Association"; N.F. Jones, The Associations of Classical Athens; C. Jones, "Embedded Written Documents as Colonial Mimicry,” BI 26 (2018): 158-81. 
to his role during the reign of that same King Artaxerxes I. Since we have the seals of one Yeho 'ezer, who was governor of Yehud in the mid-fifth century, we may propose that Yeho' ezer is the actual name of the second protagonist, and that we have a fragment of his actual report to the king.

In addition to these two protagonists who speak in the first person, we have in Neh 10 the text of a document which commits the undersigned priests and Levites to the care and provision of the temple and its priesthood. The first signer of this document is Nehemiah Attiršātā ben Hacaliah. Because the personal name Attiršātā is so rare, it is likely that this first signer of this temple document was the same man, called only by his Persian name, Attiršātā, who directed the temple priesthood in the days of the first return, under Cyrus and Darius I, and who created the document now in Neh 10. 